\title{
Effects of Preparation Conditions on Surface and Catalytic Properties of Copper and Zinc Mixed Oxides System
}

\author{
Gamil A. El-Shobaky ${ }^{*}$,, Naema S. Yehia ${ }^{\text {, }}$ Abdel-Nasser A. El-Hendawy ${ }^{\mathrm{a}}$, \\ Reham M.M. Abo-Elenin and Abdel Rahman A.A. Badawy ${ }^{\mathrm{a}}$ \\ ${ }^{a}$ Physical Chemistry Department, National Research Center, Dokki, Cairo, Egypt \\ ${ }^{b}$ Chemistry Department, Faculty of Science, Menoufia University, Shebin El-Kom, Egypt
}

\begin{abstract}
Copper-zinc mixed oxides treated with small amounts of alumina and having the formula $0.5 \mathrm{CuO}: 0.5 \mathrm{ZnO}$ : $0.05 \mathrm{Al}_{2} \mathrm{O}_{3}$ were prepared by coprecipitation of their mixed hydroxides from their mixed nitrates solutions using $1 \mathrm{M}$ $\mathrm{NaOH}$ solution. The precipitation was carried out at different $\mathrm{pH}$ values varying between 7 to 9.5 and at 50 and $70^{\circ} \mathrm{C}$.

The results revealed that the bulk of various solids consisted of $\mathrm{CuO}$ and $\mathrm{ZnO}$ having ratios varying between 0.91 and 1.20. While the surface $\mathrm{Cu} / \mathrm{Zn}$ ratio was bigger than those present in the bulk and varied between 1.16 to 1.64 depending on the $\mathrm{pH}$ value and calcination temperature. The mixed oxide solids existed as nanocrystalline $\mathrm{CuO}$ and $\mathrm{ZnO}$ phases. The surface characteristics are strongly dependent on both the $\mathrm{pH}$ value and calcination temperature. The computed $\mathrm{S}_{\mathrm{BET}}$ values varied between 21 and $108 \mathrm{~m}^{2} / \mathrm{g}$ and all adsorbents are mesoporous solids. The prepared solids showed a good catalytic activity in $\mathrm{CO}$ oxidation by $\mathrm{O}_{2}$ which proceeds via first order kinetics in all cases. The activation energy of the catalyzed reaction was determined for various solids and the computed values were very small indicating the big catalytic activity of the investigated solids.
\end{abstract}

Keywords: $\mathrm{CO}$ oxidation, $\mathrm{CuO}$ and $\mathrm{ZnO}$ catalyst, nanocrystalline.

\section{INTRODUCTION}

Recent advances in the synthesis and characterization of nanoscale materials have promoted extensive searches describing methods of preparation of highly efficient nanostructured catalysts for the removal of chemical contaminants and harmful gases such as $\mathrm{SO}_{2}$ and $\mathrm{CO}$ [1-8]. $\mathrm{CO}$ oxidation is a serious environmental concern, since exposure to few ppm of this odorless invisible gas can be fatal [9]. Therefore, there is a need to develop highly active $\mathrm{CO}$ oxidation catalysts to remove even a small amount of $\mathrm{CO}$ from the local environment. The catalytic oxidation of $\mathrm{CO}$ by $\mathrm{O}_{2}$ is of environmental and industrial importance and is being used in a wide variety of practical applications [10-14]. CO oxidation catalysts with high activities near room temperature have several applications, including closed cycle $\mathrm{CO}_{2}$ lasers and air purification devices [15-18].

Most industrialized nations have established environmental regulations to control air emissions. Issues such as the greenhouse effect and ozone layer depletion have received special attention because of dramatic and potentially disastrous consequences being anticipated by environmental scientists. The main sources of air pollution are power plants, industrial plants and automobiles. Automotive transport is very popular and the number of cars in circulation has considerably increased especially in urban areas. Motors vehicles generate more air pollution than any other single

*Address correspondence to this author at the Physical Chemistry Department, National Research Center, Dokki, Cairo, Egypt; Fax: +20-2-3370931; E-mail: elshobaky@yahoo.com human activity; they are the dominant source of carbon monoxide, oxides of nitrogen and hydrocarbons.

$\mathrm{CuO}$ - ZnO- based catalysts are used in water-gas shift reaction at low temperature [19]. Cen Yaqing et al. [20] have reported that the $\mathrm{pH}$ value was important parameter for the preparation of $\mathrm{CuO}-\mathrm{ZnO}$ catalyst by adopting coprecipitation method. This study showed that with increasing $\mathrm{pH}$ value on alkali side, the activity of the catalyst first increases and then decreases and the catalyst prepared at the $\mathrm{pH}$ value on an alkali side of 9.5 has the biggest activity.

The effect of $\mathrm{Li}_{2} \mathrm{O}$ - doping on surface and catalytic properties of $\mathrm{CuO}-\mathrm{ZnO} / \mathrm{Al}_{2} \mathrm{O}_{3}$ in $\mathrm{CO}$ - oxidation by $\mathrm{O}_{2}$ at $150-$ $200{ }^{\circ} \mathrm{C}$ has been investigated by El-Shobaky et al. [21]. These authors claimed that $\mathrm{Li}_{2} \mathrm{O}$-doping caused a measurable increase in the specific surface area $(23-45 \%)$ and in the total pore volume $(24-43 \%)$ of the adsorbents being calcined at $600-700^{\circ} \mathrm{C}$. If the doping process was carried out at $600^{\circ} \mathrm{C}$, it resulted in a considerable decrease $(52 \%)$ in the catalytic activity, in $\mathrm{CO}$ oxidation by $\mathrm{O}_{2}$, measured at $175^{\circ} \mathrm{C}$. A rise in calcination temperature of the doped catalysts (4.5 mol.\% $\mathrm{Li}_{2} \mathrm{O}$ ) from 600 to 700 or $800^{\circ} \mathrm{C}$ brought about a significant increase of $(125 \%$ and $186 \%$, respectively) in the catalytic activity measured at $175^{\circ} \mathrm{C}$. This discrepancy was discussed in terms of the effect of $\mathrm{Li}_{2} \mathrm{O}$ - doping in decreasing the dispersity of $\mathrm{CuO}$ crystallites of the solids calcined at $600^{\circ} \mathrm{C}$ and the role of $\mathrm{Li}_{2} \mathrm{O}$ in hindering $\mathrm{CuAl}_{2} \mathrm{O}_{4}$ formation upon calcination at 700 or $800^{\circ} \mathrm{C}$. The decrease in the degree of dispersion of $\mathrm{CuO}$ crystallites due to doping at $600^{\circ} \mathrm{C}$ is normally followed by a decrease in the catalytic activity while the suppression or hindrance of $\mathrm{CuAl}_{2} \mathrm{O}_{4}$ formation 
might be followed by an increase in the catalytic activity. The doping process carried out at $600-800^{\circ} \mathrm{C}$ did not modify the concentration of catalytically active constituents involved in chemisorption and catalysis of the $\mathrm{CO}$ oxidation reaction.

The present work reports the results concerning the effect of $\mathrm{pH}$ value, coprecipitation and calcination temperatures on surface and catalytic properties of $\mathrm{CuO} / \mathrm{ZnO}$ prepared by coprecipitation and treated with very small amount of $\mathrm{Al}_{2} \mathrm{O}_{3}$. The techniques employed were atomic absorption, XRD, EDX, nitrogen adsorption at $-196{ }^{\circ} \mathrm{C}$ and catalysis of $\mathrm{CO}$ oxidation by $\mathrm{O}_{2}$ at $100-200{ }^{0} \mathrm{C}$ using a static method.

\section{EXPERIMENTAL}

\subsection{Materials}

The chemicals employed were of analytical grade as supplied by Aldrich and Merck companies.

Stock solutions of copper and zinc nitrates containing 0.5 mol per liter were prepared, the required amount of aluminum nitrate was taken as a solid and dissolved in a required volume of zinc nitrate solution.

The mixed hydroxides were prepared from their nitrate solutions using $1 \mathrm{M}$ of sodium hydroxide solution. The rate of dropping of mixed nitrates and sodium hydroxide solutions was controlled in order to keep the $\mathrm{pH}$ of coprecipitation medium constant at a fixed $\mathrm{pH}$ value. The coprecipitation process was carried out at 50 and $70{ }^{\circ} \mathrm{C}$ at various $\mathrm{pH}$ values namely $7,8.5$ and 9.5 . The coprecipitation process was carried out by taking $50 \mathrm{ml}$ of zinc, aluminum mixed nitrates followed by complete coprecipitation of their mixed hydroxides with vigorous stirring followed by dropwise addition of the required volume of copper nitrate $(50 \mathrm{ml})$ with subsequent dropwise addition of copper nitrate till complete coprecipitation of all mixed hydroxides.

\subsection{Techniques}

Copper, zinc ratio in the bulk of different mixed solids calcined at $400{ }^{\circ} \mathrm{C}$ was determined by using Varian Spectra AA atomic absorption spectrometer. The analysis was carried out at $4 \mathrm{~mA}$ lamp current, acetylene fuel, nitrous oxide as support, slite width $0.1 \mathrm{~nm}$ and $327.4 \mathrm{~nm}$ wavelength for determination of copper and $213.9 \mathrm{~nm}$ wavelength for determination of zinc. A known weight $(200 \mathrm{mg})$ of each solid was dissolved in a minimum volume of hydrochloric acid followed by dilution by distilled water to $100 \mathrm{ml}$.

EDX measurements were carried out on a Hitachi S-800 electron microscope with a Kevex Delta system attached. The parameters were as follows : - $15 \mathrm{kV}$ accelerating voltage, $100 \mathrm{~s}$ accumulation time, $8 \mu \mathrm{m}$ window width. The surface molar composition was determined by the Asa method (Zaf-correction, Gaussian approximation)

$\mathrm{X}$ - ray powder diffractograms of various investigated solids calcined at 300,350 and $400{ }^{\circ} \mathrm{C}$ were determined using a Bruker diffractometer (Bruker D8 advance target ). The scanning rate was fixed at $8^{\circ}$ in $2 \theta \mathrm{min}^{-1}$ for phase identification and $0.8^{\circ}$ in $2 \theta \mathrm{min}^{-1}$ for line broadening profile analysis, respectively. The patterns were run with $\mathrm{Cu} \mathrm{K \alpha l}$ with secondly monochromator $(\lambda=0.15405 \mathrm{~nm})$ at $40 \mathrm{kV}$ and 40 $\mathrm{mA}$. The crystallite size of crystalline phases present in different solids investigated was calculated from the line broadening profile analysis of the main diffraction lines of the crystalline phases present using the Scherrer equation [22].

$$
\mathrm{d}=\frac{\mathrm{K} \lambda}{\beta_{1 / 2} \cos \theta}
$$

where $d$ is the mean crystallite diameter, $\lambda$ the $X$-ray wave length, $K$ the Scherrer constant (0.89), $\beta_{1 / 2}$ the full-width at half-maximum (FWHM) of the main diffraction peak of crystalline phases, expressed in radian, and $\theta$ is the diffraction angle.

The specific surface area $\left(\mathrm{S}_{\mathrm{BET}}\right)$, total pore volume $\left(\mathrm{V}_{\mathrm{p}}\right)$ and mean pore radius $\left(\mathrm{r}^{-}\right)$of the various adsorbents were determined from nitrogen adsorption isotherms measured at $-196{ }^{\circ} \mathrm{C}$ using NOVA Automated Gas sorbometer. The values of $\mathrm{V}_{\mathrm{p}}$ were computed from the relation

$\mathrm{V}_{\mathrm{p}}=15.45 \times 10^{-4} \times \mathrm{V}_{\mathrm{st}} \mathrm{cm}^{3} / \mathrm{g}$, where $\mathrm{V}_{\text {st }}$ is the volume of nitrogen adsorbed at $\mathrm{P} / \mathrm{P}^{0}$ tends to unity. The values of $\mathrm{r}$ were determined from the equation

$$
\mathrm{r}^{-}=\frac{2 \mathrm{~V}_{\mathrm{p}}}{\mathrm{S}_{\mathrm{BET}}} \times 10^{4} \AA
$$

The catalytic activities of different prepared solids calcined at $400{ }^{\circ} \mathrm{C}$ were determined by following up the kinetics of $\mathrm{CO}$ oxidation by $\mathrm{O}_{2}$ over various catalysts at 100,150 and $200{ }^{\circ} \mathrm{C}$. A $100 \mathrm{mg}$ of catalyst sample, activated by heating at $350{ }^{\circ} \mathrm{C}$ under a reduced pressure of $10^{-6}$ Torr, was taken in each kinetic experiment. The reaction was monitored by measuring the pressure of the reacting gas mixture $\left(\mathrm{CO}+1 / 2 \mathrm{O}_{2}\right)$ at different time intervals till no further change in pressure was attained. The initial pressure of $\left(\mathrm{CO}+1 / 2 \mathrm{O}_{2}\right)$ was fixed at 2 Torr. The reaction product $\left(\mathrm{CO}_{2}\right)$ was removed from the reaction atmosphere by freezing at liquid nitrogen temperature. So, the percentage decrease of the pressure of the reacting gases at a given time interval determines the percentage conversion of the catalytic reaction at that time. The saturation vapour pressure of $\mathrm{CO}$ at $-196{ }^{\circ} \mathrm{C}$ being 160 Torr makes its liquefaction at that pressure improbable under the employed conditions (2 Torr)[23].

\section{RESULTS AND DISCUSSION}

\subsection{Spectroscopic Determination of Copper: Zinc Ratio}

$\mathrm{Cu} / \mathrm{Zn}$ ratio in the bulk of solids was determined spectroscopically using solids calcined at $400{ }^{\circ} \mathrm{C}$ and being prepared under different conditions. The results obtained are given in the last column of Table 1. Examination of Table $\mathbf{1}$ shows that $\mathrm{Cu} / \mathrm{Zn}$ ratio in the bulk of the solids investigated, being coprecipitated under different conditions and calcined at $400{ }^{\circ} \mathrm{C}$, varied between 0.91 and 1.20 depending on coprecipitation temperature and $\mathrm{pH}$ value. The biggest ratio was obtained for the solids coprecipitated at the smallest $\mathrm{pH}$ (7) and highest temperature $\left(70{ }^{\circ} \mathrm{C}\right)$. While the smallest ratio was observed for the solids coprecipitated at the biggest $\mathrm{pH}$ (9.5) and highest temperature $\left(70{ }^{\circ} \mathrm{C}\right)$. These findings could be attributed to the amophoteric nature of $\mathrm{Zn}(\mathrm{OH})_{2}$ leading to a possible dissolution of a small portion of $\mathrm{Zn}(\mathrm{OH})_{2}$ precipitate in solution having a $\mathrm{pH}=9.5$. 
Table1. Surface and Bulk Molar Composition of $\mathrm{CuO}-\mathrm{ZnO}$ and $\mathrm{Al}_{2} \mathrm{O}_{3}$ System Prepared at Different pH Values and Preparation Temperature Determined by EDX and Atomic Absorption

\begin{tabular}{|c|c|c|c|c|c|c|c|c|}
\hline \multirow{2}{*}{ Solid } & \multirow{2}{*}{$\begin{array}{c}\text { Preparation } \\
\text { pH }\end{array}$} & \multirow{2}{*}{$\begin{array}{l}\text { Preparation } \\
\text { Temperature }\end{array}$} & \multirow{2}{*}{$\begin{array}{c}\text { Calcination } \\
\text { Temperature, }{ }^{\circ} \mathrm{C}\end{array}$} & \multirow{2}{*}{ Element } & \multicolumn{2}{|c|}{ Atomic Abundance } & \multirow{2}{*}{$\begin{array}{c}\text { Surface Cu / Zn } \\
\text { Ratio }\end{array}$} & \multirow{2}{*}{$\begin{array}{c}\text { Bulk } \\
\text { Cu / Zn Ratio }\end{array}$} \\
\hline & & & & & $\begin{array}{c}\text { Calculated } \\
\text { (Bulk) }\end{array}$ & $\begin{array}{l}\text { Found } \\
\text { (Surface) }\end{array}$ & & \\
\hline \multirow{3}{*}{ Sample 1} & \multirow{3}{*}{8.5} & \multirow{3}{*}{$\begin{array}{c}50{ }^{\circ} \mathrm{C} \text { ageing } \\
1 \mathrm{~h} \text { at } 50^{\circ} \mathrm{C}\end{array}$} & 300 & $\begin{array}{c}\mathrm{Cu} \\
\mathrm{Zn} \\
\mathrm{O} \\
\mathrm{Al}\end{array}$ & $\begin{array}{c}22.2 \\
22.2 \\
51.1 \\
4.5\end{array}$ & $\begin{array}{c}25.6 \\
19.3 \\
54.4 \\
0.7\end{array}$ & 1.33 & \\
\hline & & & 350 & $\begin{array}{c}\mathrm{Cu} \\
\mathrm{Zn} \\
\mathrm{O} \\
\mathrm{Al}\end{array}$ & $\begin{array}{c}22.2 \\
22.2 \\
51.1 \\
4.5\end{array}$ & $\begin{array}{c}24.5 \\
19.1 \\
54.4 \\
2.0\end{array}$ & 1.28 & \\
\hline & & & 400 & $\begin{array}{c}\mathrm{Cu} \\
\mathrm{Zn} \\
\mathrm{O} \\
\mathrm{Al}\end{array}$ & $\begin{array}{c}22.2 \\
22.2 \\
51.1 \\
4.5\end{array}$ & $\begin{array}{c}23.8 \\
20.6 \\
53.8 \\
1.8\end{array}$ & 1.16 & 0.93 \\
\hline \multirow{3}{*}{ Sample 2} & \multirow{3}{*}{9.5} & \multirow{3}{*}{$\begin{array}{c}50{ }^{\circ} \mathrm{C} \text { ageing } \\
1 \mathrm{~h} \text { at } 50{ }^{\circ} \mathrm{C}\end{array}$} & 300 & $\begin{array}{c}\mathrm{Cu} \\
\mathrm{Zn} \\
\mathrm{O} \\
\mathrm{Al}\end{array}$ & $\begin{array}{c}22.2 \\
22.2 \\
51.1 \\
4.5\end{array}$ & $\begin{array}{c}24.8 \\
19.6 \\
53.6 \\
2.0\end{array}$ & 1.26 & \\
\hline & & & 350 & $\begin{array}{c}\mathrm{Cu} \\
\mathrm{Zn} \\
\mathrm{O} \\
\mathrm{Al} \\
\end{array}$ & $\begin{array}{c}22.2 \\
22.2 \\
51.1 \\
4.5 \\
\end{array}$ & $\begin{array}{c}24.0 \\
18.5 \\
53.5 \\
4.0 \\
\end{array}$ & 1.30 & \\
\hline & & & 400 & $\begin{array}{c}\mathrm{Cu} \\
\mathrm{Zn} \\
\mathrm{O} \\
\mathrm{Al}\end{array}$ & $\begin{array}{c}22.2 \\
22.2 \\
51.1 \\
4.5\end{array}$ & $\begin{array}{c}24.4 \\
17.8 \\
54.1 \\
3.7\end{array}$ & 1.37 & 0.98 \\
\hline \multirow{3}{*}{ Sample 3} & \multirow{3}{*}{7} & \multirow{3}{*}{$\begin{array}{c}70^{\circ} \mathrm{C} \text { ageing } \\
1 \mathrm{~h} \text { at } 70^{\circ} \mathrm{C}\end{array}$} & 300 & $\begin{array}{c}\mathrm{Cu} \\
\mathrm{Zn} \\
\mathrm{O} \\
\mathrm{Al} \\
\end{array}$ & $\begin{array}{c}22.2 \\
22.2 \\
51.1 \\
4.5 \\
\end{array}$ & $\begin{array}{c}27.5 \\
16.8 \\
53.9 \\
1.8 \\
\end{array}$ & 1.64 & \\
\hline & & & 350 & $\begin{array}{c}\mathrm{Cu} \\
\mathrm{Zn} \\
\mathrm{O} \\
\mathrm{Al}\end{array}$ & $\begin{array}{c}22.2 \\
22.2 \\
51.1 \\
4.5\end{array}$ & $\begin{array}{c}27.7 \\
17.3 \\
54.5 \\
0.5\end{array}$ & 1.60 & \\
\hline & & & 400 & $\begin{array}{c}\mathrm{Cu} \\
\mathrm{Zn} \\
\mathrm{O} \\
\mathrm{Al}\end{array}$ & $\begin{array}{c}22.2 \\
22.2 \\
51.1 \\
4.5 \\
\end{array}$ & $\begin{array}{c}24.6 \\
19.3 \\
54.6 \\
1.5 \\
\end{array}$ & 1.28 & 1.20 \\
\hline \multirow{3}{*}{ Sample 4} & \multirow{3}{*}{7} & \multirow{3}{*}{$\begin{array}{l}70{ }^{\circ} \mathrm{C} \text { without } \\
\text { ageing }\end{array}$} & 300 & $\begin{array}{c}\mathrm{Cu} \\
\mathrm{Zn} \\
\mathrm{O} \\
\mathrm{Al}\end{array}$ & $\begin{array}{c}22.2 \\
22.2 \\
51.1 \\
4.5\end{array}$ & $\begin{array}{c}25.0 \\
19.4 \\
53.7 \\
1.9\end{array}$ & 1.29 & \\
\hline & & & 350 & $\begin{array}{c}\mathrm{Cu} \\
\mathrm{Zn} \\
\mathrm{O} \\
\mathrm{Al}\end{array}$ & $\begin{array}{c}22.2 \\
22.2 \\
51.1 \\
4.5\end{array}$ & $\begin{array}{c}24.4 \\
19.9 \\
54.2 \\
1.5\end{array}$ & 1.23 & \\
\hline & & & 400 & $\begin{array}{c}\mathrm{Cu} \\
\mathrm{Zn} \\
\mathrm{O} \\
\mathrm{Al}\end{array}$ & $\begin{array}{c}22.2 \\
22.2 \\
51.1 \\
4.5\end{array}$ & $\begin{array}{c}23.8 \\
20.3 \\
54.3 \\
1.6 \\
\end{array}$ & 1.17 & 1.10 \\
\hline \multirow{3}{*}{ Sample 5} & \multirow{3}{*}{9.5} & \multirow{3}{*}{$\begin{array}{c}70{ }^{\circ} \mathrm{C} \text { ageing } \\
1 \mathrm{~h} \text { at } 70{ }^{\circ} \mathrm{C}\end{array}$} & 300 & $\begin{array}{c}\mathrm{Cu} \\
\mathrm{Zn} \\
\mathrm{O} \\
\mathrm{Al}\end{array}$ & $\begin{array}{c}22.2 \\
22.2 \\
51.1 \\
4.5\end{array}$ & $\begin{array}{c}23.4 \\
20.1 \\
54.1 \\
2.4\end{array}$ & 1.16 & \\
\hline & & & 350 & $\begin{array}{c}\mathrm{Cu} \\
\mathrm{Zn} \\
\mathrm{O} \\
\mathrm{Al}\end{array}$ & $\begin{array}{c}22.2 \\
22.2 \\
51.1 \\
4.5\end{array}$ & $\begin{array}{c}23.2 \\
19.1 \\
54.4 \\
3.3\end{array}$ & 1.21 & \\
\hline & & & 400 & $\begin{array}{c}\mathrm{Cu} \\
\mathrm{Zn} \\
\mathrm{O} \\
\mathrm{Al}\end{array}$ & $\begin{array}{c}22.2 \\
22.2 \\
51.1 \\
4.5\end{array}$ & $\begin{array}{c}24.7 \\
19.3 \\
54.1 \\
1.9\end{array}$ & 1.28 & 0.91 \\
\hline
\end{tabular}




\subsection{Energy Dispersive X-Ray (EDX) Analysis of Various Solids}

EDX investigation was carried out for $\mathrm{CuO} / \mathrm{ZnO}$ system treated with $0.05 \mathrm{~mol} \mathrm{Al}_{2} \mathrm{O}_{3} /$ mol solid prepared under different conditions and calcined at $300-400{ }^{\circ} \mathrm{C}$. The relative atomic abundance of $\mathrm{Cu}, \mathrm{Zn}, \mathrm{Al}$ and oxygen species present in the uppermost surface layers of different solids investigated is given in Table 1. It is well known that EDX technique supplies the effective atomic concentration of different constituents of the solids investigated present on their top surface layers. The thickness of these layers is bigger than that measured using XPS technique. This difference is due to the bigger value of the energy of X-ray beam in case of the EDX as compare to that in case of XPS technique. Also, enclosed in Table $\mathbf{1}$ are the values of atomic abundance of $\mathrm{Cu}, \mathrm{Zn}, \mathrm{Al}$ and oxygen present in the bulk (calculated) of various solids. Examination of Table 1 shows the following: (i) The surface $\mathrm{Cu} / \mathrm{Zn}$ ratio in the solids prepared under varying conditions and calcined at $300-400{ }^{\circ} \mathrm{C}$ is strongly dependent on $\mathrm{pH}$ values, preparation and calcination temperatures.(ii) The surface concentrations of $\mathrm{Cu}$ in all solids investigated is bigger than that in the bulk of these solids. On the other hand, the surface zinc and aluminum concentration are smaller than those present in the bulk of different solids. (iii) The surface copper, zinc ratio in mixed solids prepared at $\mathrm{pH}=8.5$ at $50{ }^{\circ} \mathrm{C}$ (sample 1) and calcined at $400{ }^{\circ} \mathrm{C}$ and mixed solids prepared at $\mathrm{pH}=9.5$ at $70{ }^{\circ} \mathrm{C}$ (sample 5) and calcined at $300^{\circ} \mathrm{C}$ showed the smallest copper zinc ratio (iv) The surface copper, zinc ratio in the mixed solids prepared at $\mathrm{pH}=7$ at $70^{\circ} \mathrm{C}$ (sample 3 ) and being calcined at $300^{\circ} \mathrm{C}$ measured the biggest value. (v)The small value of $\mathrm{pH}$ gave higher copper/zinc ratio. This finding might be discussed in terms of the difference in solubility product of $\mathrm{Cu}(\mathrm{OH})_{2}$ and $\mathrm{Zn}(\mathrm{OH})_{2}$ which measures $4.8 \times 10^{-20}$ and $1.2 \times 10^{-17}$, respectively. These values suggest an earlier precipitation of $\mathrm{Zn}(\mathrm{OH})_{2}$ prior to $\mathrm{Cu}(\mathrm{OH})_{2}$. (vi) The rise in calcination temperature of solids prepared at high $\mathrm{pH}$ value $(\mathrm{pH}=9.5)$ [samples 2,5] within 300 and $400{ }^{\circ} \mathrm{C}$ resulted in a progressive increase in surface copper zinc ratio. This increase may express a possible migration of copper species from bulk to surface opposite to the concentration gradient.(vii) The rise in calcination temperature of solids prepared at lower $\mathrm{pH}$ value $(\mathrm{pH}=7$ or 8.5$)$ [samples $1,3,4]$ within 300 and $400{ }^{\circ} \mathrm{C}$ resulted in a progressive decrease in surface copper zinc ratio.

\subsection{X-Ray Investigation of Different Solids}

The X-ray diffractograms of different solids prepared under varying conditions and being calcined at 300, 350 and $400{ }^{\circ} \mathrm{C}$ were determined.

Figs. $(\mathbf{1}, \mathbf{2})$ show representative $\mathrm{X}$-ray diffractograms of different calcined solids prepared at $\mathrm{pH}=8.5$ and 9.5 at $50{ }^{\circ} \mathrm{C}$ (sample 1,2). The different structural characteristics of various investigated solids were determined and the results obtained are given in Table 2 . These characteristics include the identification of different phases present, their crystallite size and degree of crystallinity. Examination of this Table shows the following: (i) The different investigated solids calcined at $300-400{ }^{\circ} \mathrm{C}$ consisted of nanocrystalline $\mathrm{CuO}$, $\mathrm{ZnO}$ phases. (ii) The crystallite size of both $\mathrm{CuO}$ and $\mathrm{ZnO}$ phases prepared at high temperature $\left(70{ }^{\circ} \mathrm{C}\right)$ [samples 3,4,5] or at high $\mathrm{pH}$ values [sample 2] increases progressively as a function of calcination temperature. (iii) The crystallite size of $\mathrm{CuO}$ and $\mathrm{ZnO}$ phases in the solids prepared at $\mathrm{pH}=9.5$, $50^{\circ} \mathrm{C}$ and being calcined at different temperatures measured the smallest values.(iv) The crystallite size of both $\mathrm{CuO}$ and $\mathrm{ZnO}$ phases present in solids prepared at low temperature and at $\mathrm{pH}=8.5$ [sample 1] decreases progressively as a function of calcination temperature.

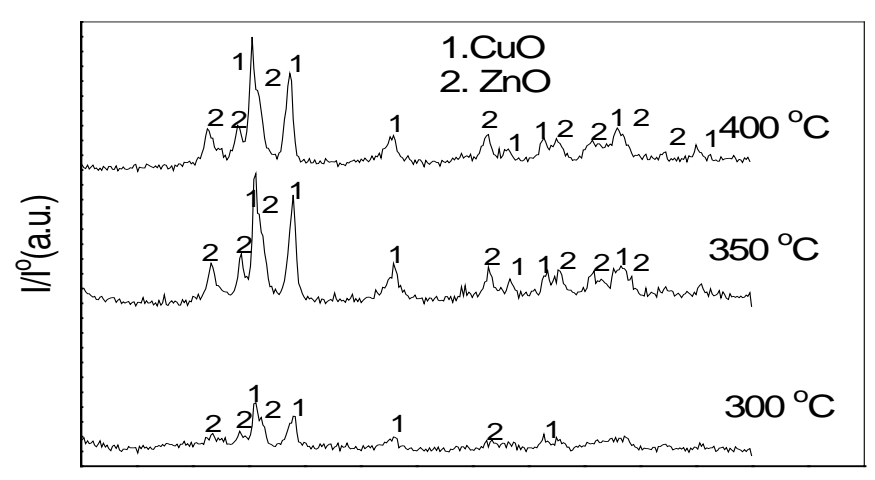

$2 \theta$ degree

Fig. (1). X-ray diffractograms of sample 1 and being calcined at 300,350 and and $400{ }^{\circ} \mathrm{C}$.

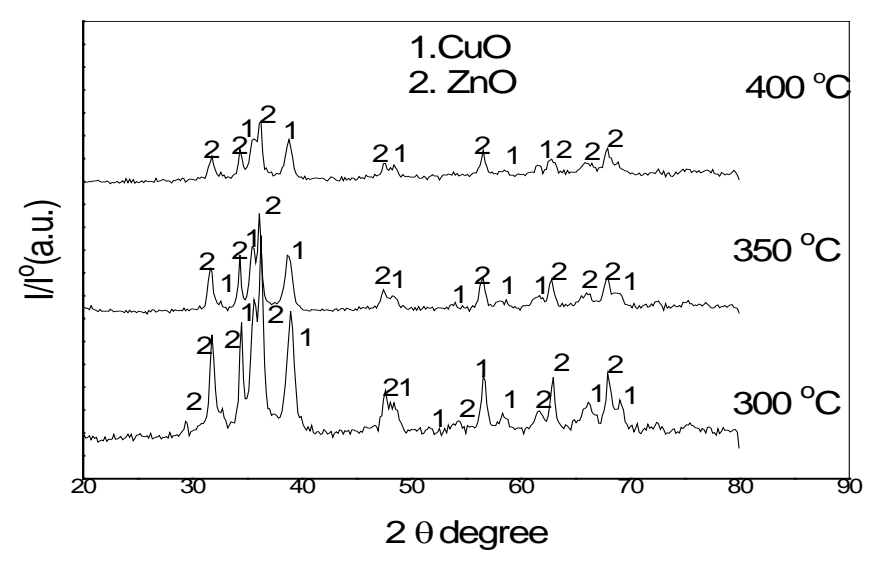

Fig. (2). X-ray diffractograms of sample 4 and being calcined at 300,350 and $400{ }^{\circ} \mathrm{C}$.

\subsection{Surface Characteristics of Different Solids}

The different surface characteristics of various solids were determined from analysis of nitrogen adsorption isotherms carried out at $-196{ }^{\circ} \mathrm{C}$ over various adsorbents. These characteristics include specific surface areas $\left(\mathrm{S}_{\mathrm{BET}}\right)$, total pore volume $\left(\mathrm{V}_{\mathrm{p}}\right)$ and mean pore radius $\left(\mathrm{r}^{-}\right)$. The $\mathrm{S}_{\mathrm{BET}}$ values were determined from linear portion of the BET equation.

Another series of specific surface area $\left(\mathrm{S}_{\mathrm{t}}\right)$ was determined from $\mathrm{V}_{1} \mathrm{~T}$ plots constructed using suitable standard $\mathrm{T}$ curves depending on the values of the BET- $\mathrm{C}$ constant.

Figs. $(3,4)$ depict representative $\mathrm{V}_{1-} \mathrm{T}$ plots of mixed solids (samples 1,5 ) and being calcined at $300,350,400{ }^{\circ} \mathrm{C}$. The $\mathrm{V}_{1-} \mathrm{T}$ plots of all solids investigated (not given) showed 
Table 2. The Effect of pH and Preparation Temperature on the Crystallite Size and Degree of Crystallinity

\begin{tabular}{|c|c|c|c|c|c|c|c|c|}
\hline \multirow{2}{*}{ Solid } & \multirow{2}{*}{ Preparation pH } & \multirow{2}{*}{$\begin{array}{l}\text { Preparation } \\
\text { Temperature }\end{array}$} & \multirow{2}{*}{$\begin{array}{c}\text { Calcination } \\
\text { Temperature, }{ }^{\circ} \mathrm{C}\end{array}$} & \multirow{2}{*}{$\begin{array}{c}\text { Major Phase } \\
\text { Present }\end{array}$} & \multicolumn{2}{|c|}{ Crystallite Size (nm) } & \multicolumn{2}{|c|}{$\begin{array}{c}\text { "Degree of } \\
\text { Crystallinity (a.u.) }\end{array}$} \\
\hline & & & & & $\mathrm{CuO}$ & $\mathrm{ZnO}$ & $\mathrm{CuO}$ & $\mathrm{ZnO}$ \\
\hline \multirow{3}{*}{ Sample 1} & \multirow{3}{*}{8.5} & \multirow{3}{*}{$\begin{array}{c}50{ }^{\circ} \mathrm{C} \text { ageing } 1 \mathrm{~h} \text { at } \\
50^{\circ} \mathrm{C}\end{array}$} & 300 & $\mathrm{CuO}$ & 19.2 & 11.8 & 36.3 & 25.2 \\
\hline & & & 350 & $\mathrm{CuO}$ & 17.3 & 10.5 & 79.2 & 31.4 \\
\hline & & & 400 & $\mathrm{CuO}$ & 13.1 & 8.5 & 93.2 & 42.7 \\
\hline \multirow{3}{*}{ Sample 2} & \multirow{3}{*}{9.5} & \multirow{3}{*}{$\begin{array}{c}50^{\circ} \mathrm{C} \text { ageing } 1 \mathrm{~h} \text { at } \\
50^{\circ} \mathrm{C}\end{array}$} & 300 & $\mathrm{CuO}$ & 7.6 & 3.9 & 53.3 & 33.7 \\
\hline & & & 350 & $\mathrm{CuO}$ & 9.0 & 7.0 & 61.1 & 36.8 \\
\hline & & & 400 & $\mathrm{CuO}$ & 11.2 & 7.9 & 72.4 & 48.5 \\
\hline \multirow{3}{*}{ Sample 3} & \multirow{3}{*}{7} & \multirow{3}{*}{$\begin{array}{c}70^{\circ} \mathrm{C} \text { ageing } 1 \mathrm{~h} \text { at } \\
70^{\circ} \mathrm{C}\end{array}$} & 300 & $\mathrm{ZnO}$ & 9.8 & 25.7 & 47.5 & 128.0 \\
\hline & & & 350 & $\mathrm{ZnO}$ & 12.8 & 28.0 & 67.5 & 106.0 \\
\hline & & & 400 & $\mathrm{ZnO}$ & 16.0 & 32.0 & 109.0 & 102.0 \\
\hline \multirow{3}{*}{ Sample 4} & \multirow{3}{*}{7} & \multirow{3}{*}{$\begin{array}{l}70{ }^{\circ} \mathrm{C} \text { without } \\
\text { ageing }\end{array}$} & 300 & $\mathrm{ZnO}$ & 12.9 & 14.1 & 155.0 & 122.0 \\
\hline & & & 350 & $\mathrm{ZnO}$ & 15.3 & 19.3 & 72.0 & 114.0 \\
\hline & & & 400 & $\mathrm{ZnO}$ & 16.5 & 29.8 & 51.7 & 76.2 \\
\hline \multirow{3}{*}{ Sample 5} & \multirow{3}{*}{9.5} & \multirow{3}{*}{$\begin{array}{c}70^{\circ} \mathrm{C} \text { ageing } 1 \mathrm{~h} \text { at } \\
70^{\circ} \mathrm{C}\end{array}$} & 300 & $\mathrm{ZnO}$ & 9.9 & 18.5 & 69.3 & 69.8 \\
\hline & & & 350 & $\mathrm{ZnO}$ & 14.8 & 23.8 & 64.2 & 71.7 \\
\hline & & & 400 & $\mathrm{ZnO}$ & 12.0 & 33.0 & 58.3 & 85.0 \\
\hline
\end{tabular}

* The peak area of the major line of each phase was taken as a measure for the degree of the degree of crystallinity.

an upward deviation indicating the domination of wide pores. However all adsorbents are considered as mesoporous adsorbents. This conclusion is reached at by comparing the values of $\mathrm{r}^{-}$given in Table 3 which shows that the $\mathrm{r}^{-}$values of all adsorbent vary between 10 and $158 \AA$.

Examination of Table 3 shows the following (i) The values of $S_{B E T}$ and $S_{t}$ for all adsorbents investigated are close to each other which justifies the correct choice of standard tcurve used in pore analysis and indicates the absence of ultramicro pores.(ii) The $\mathrm{S}_{\mathrm{BET}}$ of different solids decreases progressively by increasing the calcination temperature within $300-400{ }^{\circ} \mathrm{C}$. (iii) The mixed solids prepared at $\mathrm{pH}=7$ and $70{ }^{\circ} \mathrm{C}$ [sample 3] and being calcined at $300^{\circ} \mathrm{C}$ measured the biggest $\mathrm{S}_{\mathrm{BET}}$ value while the adsorbent prepared at $\mathrm{pH}=7$ at $70{ }^{\circ} \mathrm{C}$ [sample 3] and being calcined at $400^{\circ} \mathrm{C}$ measured the smallest $\mathrm{S}_{\mathrm{BET}}$ value. (iv)The solids prepared at $\mathrm{pH}=9.5$ and $50^{\circ} \mathrm{C}$ and being calcined at all temperatures within 300-400 ${ }^{\circ} \mathrm{C}$ measured the biggest total pore volume. While the smallest $\mathrm{Vp}$ values were measured for the mixed solids prepared at $\mathrm{pH}=7$ at $70{ }^{\circ} \mathrm{C}$ without ageing [sample 4]. (v) The increase in pre-calcination temperature of all solids from $300-400{ }^{\circ} \mathrm{C}$ led to a decrease of $14 \%, 14 \%, 81 \%, 60 \%$ and $26 \%$ for the samples $1,2,3,4$ and 5 , respectively. So, sample 3 suffered an effective sintering due to increasing its calcination temperature from $300-400{ }^{\circ} \mathrm{C}$. While samples 1 and 2 showed the smallest sinterability by increasing their calcination temperature within $300-400{ }^{\circ} \mathrm{C}$.

\subsection{Catalytic Activity of Various Solids}

The oxidation of $\mathrm{CO}$ by $\mathrm{O}_{2}$ was carried out over various prepared solids calcined at $400{ }^{\circ} \mathrm{C}$. First order kinetics was observed in all cases; the slopes of the first order plots determine the values of reaction rate constant $(\mathrm{k})$ measured at a given temperature over a given catalyst sample. Fig. (5) shows representative first order-plots of $\mathrm{CO}$ oxidation by $\mathrm{O}_{2}$ carried out at $100,150,200{ }^{\circ} \mathrm{C}$ over samples 1 and 2 . The computed $\mathrm{k}$ values measured at 100,150 and $200{ }^{\circ} \mathrm{C}$ for the investigated solids are given in Table 4. Examination of Table 4 shows the following (i) The catalytic activity of various investigated solids, expressed as reaction rate constant is strongly dependent on the conditions of preparation. (ii) The solids prepared at $\mathrm{pH}=7$ and at $70{ }^{\circ} \mathrm{C}$ [sample 3] showed the smallest catalytic activity. (iii) The solids prepared at $\mathrm{pH}=$ 8.5 and at $50{ }^{\circ} \mathrm{C}$ [sample 1] has the biggest catalytic activity at reaction temperature of $100{ }^{\circ} \mathrm{C}$. In fact, the $\mathrm{k}_{100}{ }^{\circ} \mathrm{C}$ values were between 54 to $96 \mathrm{~min}^{-1} \mathrm{~g}^{-1}$.

The main factors determining the catalytic activity are surface copper concentration (catalytically active constituent) and its crystallite size. The bigger the surface concentration of copper the bigger will be the catalytic activity and the smaller the crystallite size of $\mathrm{CuO}$ the bigger will be the catalytic activity and vice versa. In the light of these two factors the catalyst sample devoted with the biggest catalytic activity measured the smallest surface $\mathrm{Cu} / \mathrm{Zn}$ ratio [1.16 c.f. Table 1] and crystallite size of $13.1 \mathrm{~nm}$. These values are not in favour of the observed big catalytic activity of this particular sample. It seems that not all the surface copper oxide participates directly in chemisorption and catalysis in $\mathrm{CO}$ oxidation reaction. In other words, a portion of surface copper may be involved in the catalytic reaction. However, XRD investigation of the solids investigated showed that this particular sample being calcined at $400{ }^{\circ} \mathrm{C}$ consists of nanosized copper oxide as a major phase while the major phase present in other solids was $\mathrm{ZnO}$ 

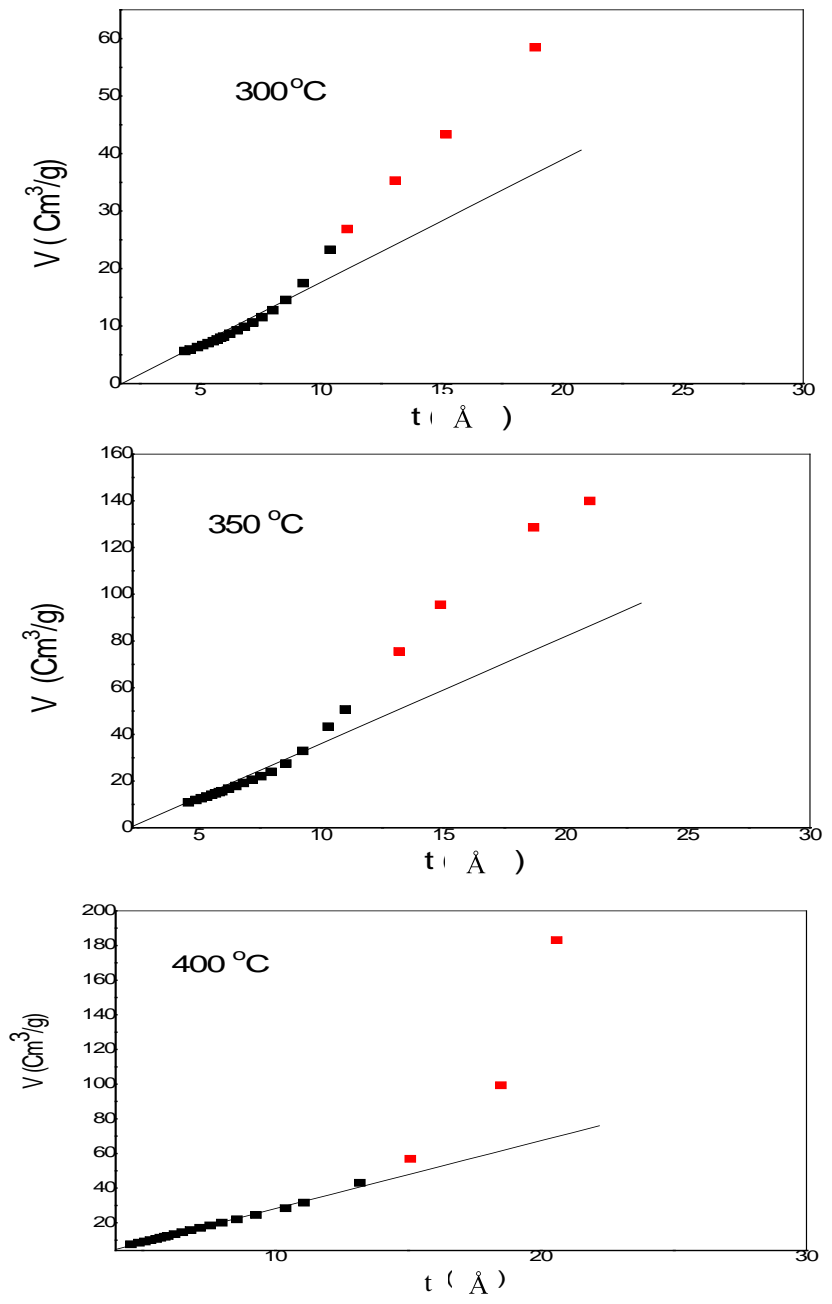

Fig. (3). Volume thickness plots $\left(\mathrm{V}_{1-\mathrm{t}}\right)$ of sample 1 and being calcined at 300,350 and $400{ }^{\circ} \mathrm{C}$

Determination of apparent activation energy $\left(\Delta \mathrm{E}_{\mathrm{a}}\right)$ of $\mathrm{CO}$ oxidation by $\mathrm{O}_{2}$ over the catalysts investigated prepared under different conditions can throw more light on the role of preparation condition of these catalysts in changing the mechanism of the catalyzed reaction. This has been done by determining the catalytic reaction rate constant $(\mathrm{k})$ measured at $100-200{ }^{\circ} \mathrm{C}$ over various solids via direct application of the Arrhenius equation. The computed $\Delta \mathrm{E}_{\mathrm{a}}$ values are given in Table 5. Examination of Table 5 shows that $\Delta \mathrm{E}_{\mathrm{a}}$ values changed from one catalyst to another and the bigger the catalytic activity of the solids investigated the smaller is the activation energy of the catalyzed reaction and vice versa. This finding expresses the observed changes in the catalytic activities of the solids investigated prepared under different conditions. In order to throw more light about the possible heterogeneity of surfaces of the investigated catalysts, the values of $\ln \mathrm{A}$ (pre-exponential factor of the Arrhenius equation) were calculated for various catalysts and the data obtained are given in the second column of Table 5. It is shown from this table that $\Delta \mathrm{E}_{\mathrm{a}}$ and $\log \mathrm{A}$ values changed from 1.7 to 10.3 which suggested the heterogeneous nature of surfaces of $\mathrm{CuO}-\mathrm{ZnO}$ mixed solids prepared at different conditions. So, the observed changes of $\Delta \mathrm{E}_{\mathrm{a}}$ could result from corresponding changes of $\ln \mathrm{A}$ values. This speculation could be
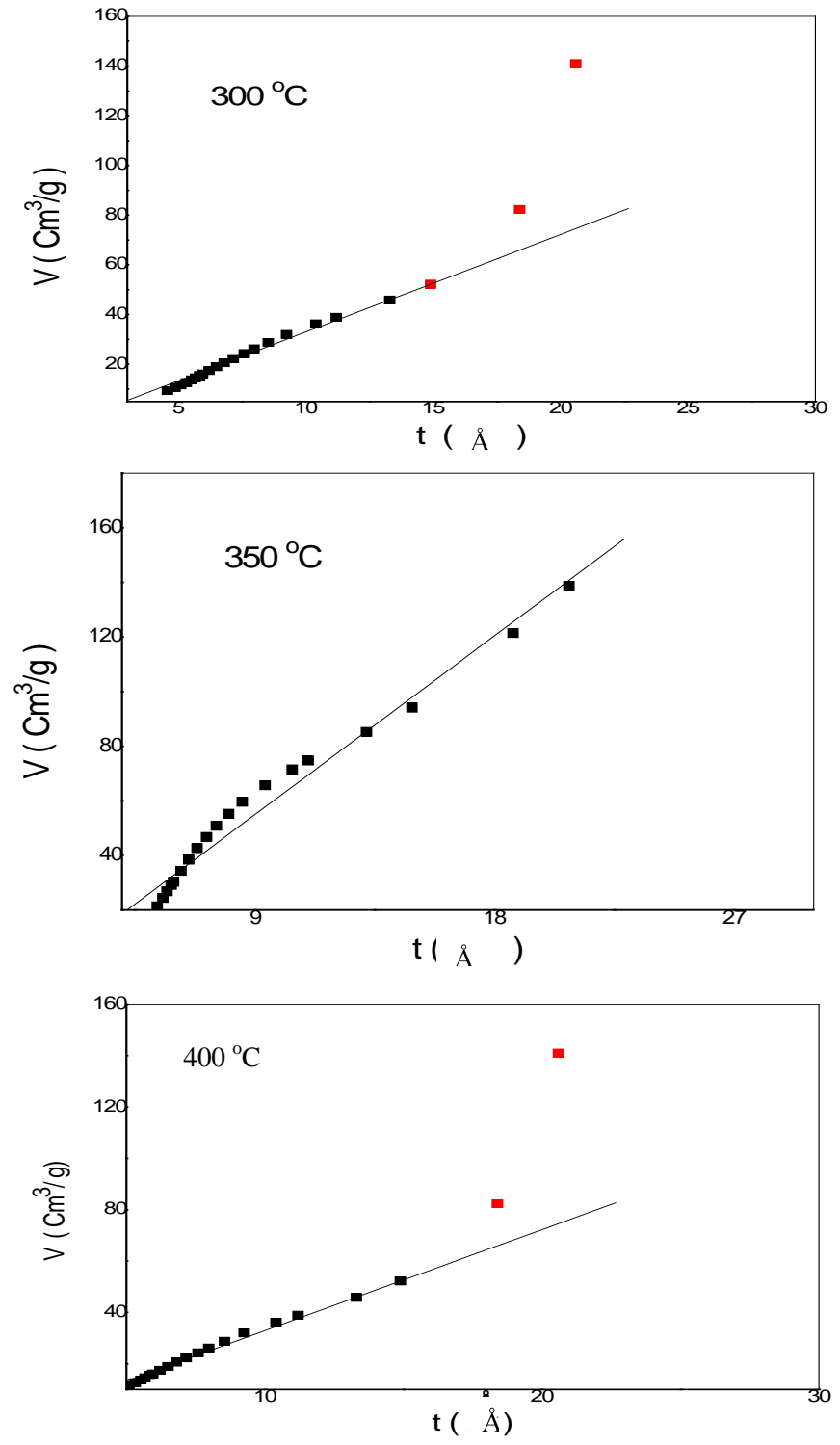

Fig. (4). Volume thickness plots (V of sample 5 and being calcined at 300,350 and $400{ }^{\circ} \mathrm{C}$.

confirmed via recalculation of $\Delta \mathrm{E}_{\mathrm{a}}$ values adopting the value of $\log \mathrm{A}$ of the solid prepared at $\mathrm{pH}=8.5$ and at $50{ }^{\circ} \mathrm{C}$ [sample 1] to the other sample prepared under the other conditions. The recalculated values of activation energy of the catalyzed reaction $\left(\Delta E^{*}\right)$ carried out over various catalysts are given in the last column of Table 5. This column shows clearly that $\Delta \mathrm{E}^{*}$ values for different solids are close to each other within the experimental error $(2.5 \pm 0.3 \mathrm{~kJ} / \mathrm{mol})$. These finding suggested that the catalytic oxidation of $\mathrm{CO}$ by $\mathrm{O}_{2}$ over the solids investigated prepared at different conditions follows the same mechanism. Furthermore, all catalysts investigated are devoted with big catalytic activities as being evidenced from the small values of $\Delta \mathrm{E}_{\mathrm{a}}$.

The heterogeneity of surfaces of the catalysts investigated may find another evidence from the plot of the equation $\mathrm{A}=\mathrm{a} \exp (\mathrm{h} \Delta \mathrm{E})$ derived on the basis of dissipation function of active sites by their energy as a consequence of surface heterogeneity $[24,25]: F\left(E_{i}\right)=a \exp \left(h E_{i}\right)$, where $E_{i}$ is the energy of site " $i$ " with the substrate [24]. The plot of $\ln A$ 
Table 3. Surface Characteristics of $0.5 \mathrm{CuO}-0.5 \mathrm{ZnO}-0.05 \mathrm{Al}_{2} \mathrm{O}_{3}$ System Prepared by Coprecipitation at Different pH Values and Calcined at $300-400{ }^{\circ} \mathrm{C}$

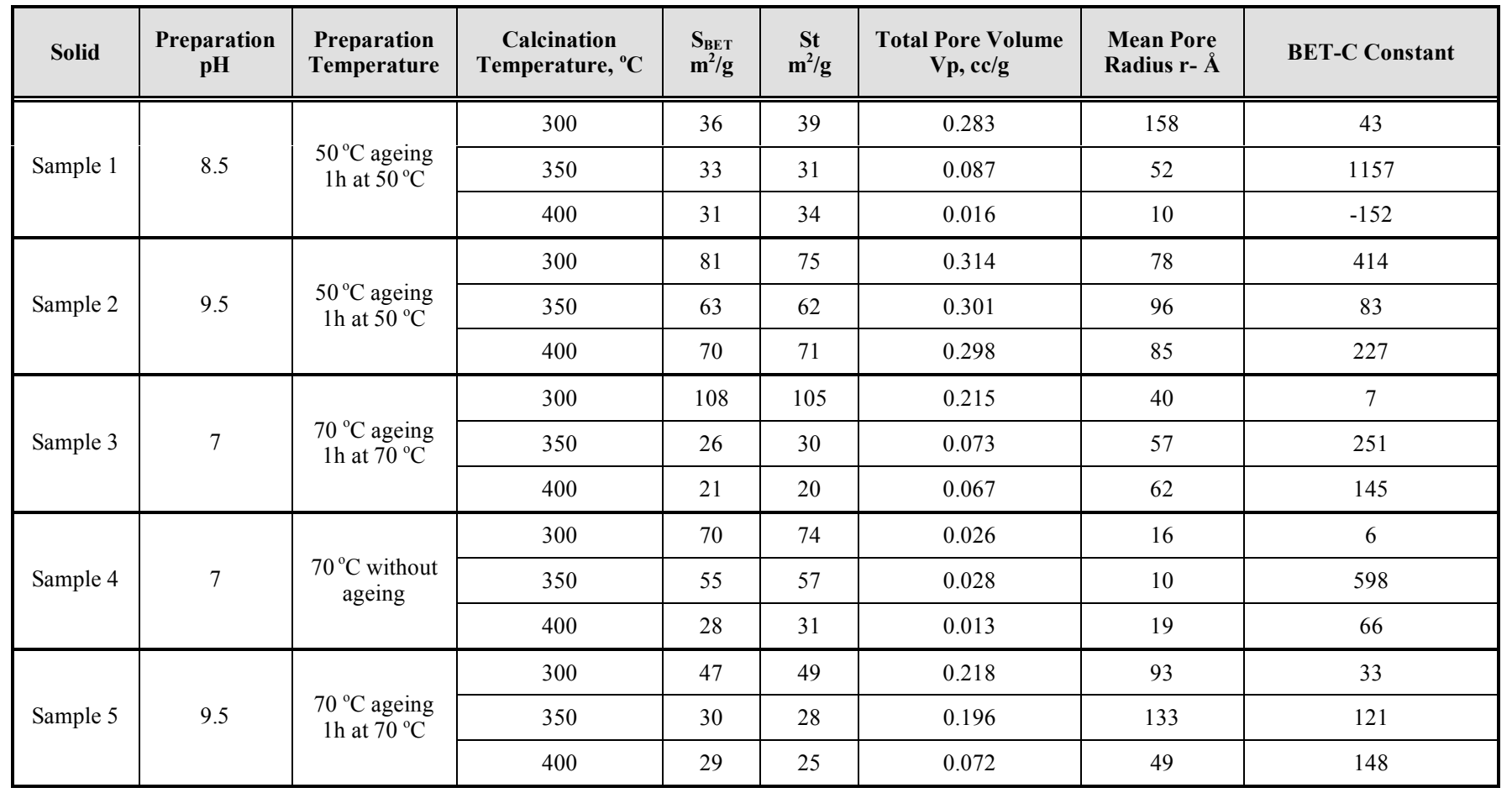

(a)

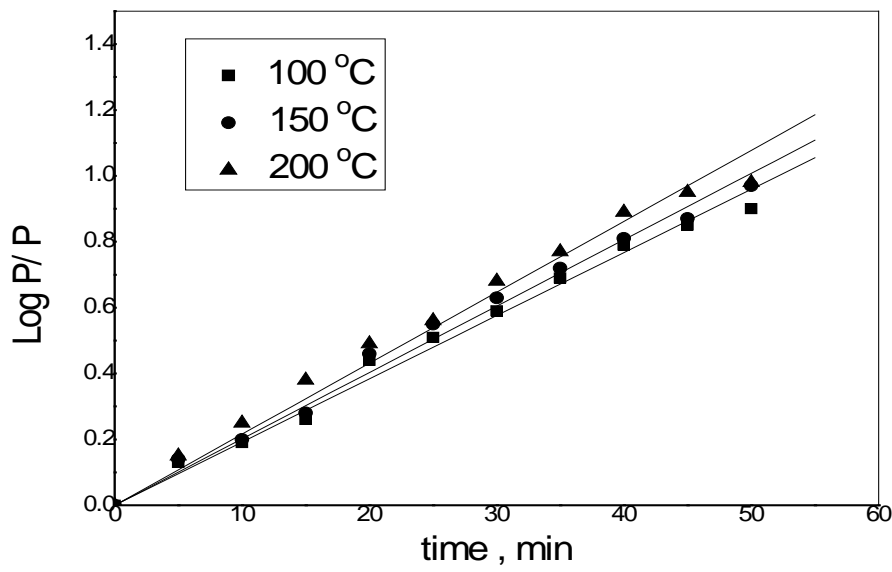

(b)

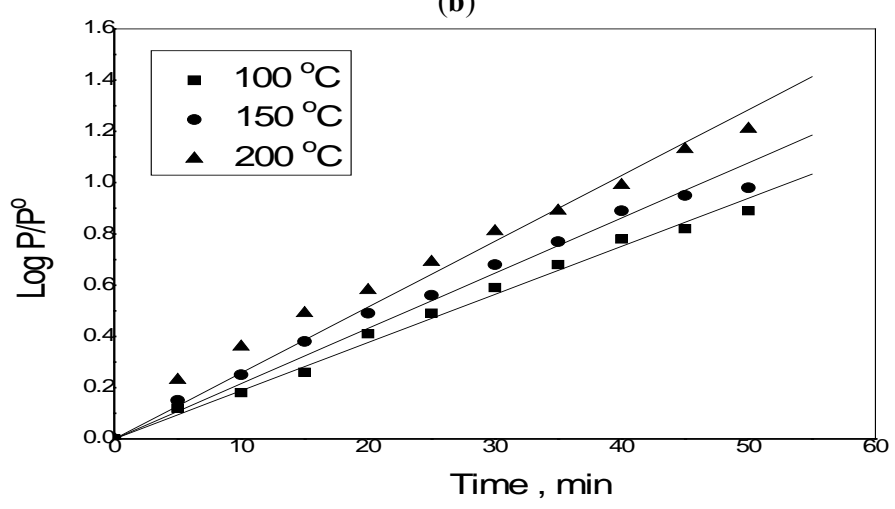

Fig. (5). First order plots of $\mathrm{CO}$ oxidation by $\mathrm{O}_{2}$ carried out at different temperatures over catalyst being calcined at $400{ }^{\circ} \mathrm{C}$ (a) sample 1. (b) sample 2. versus $\Delta \mathrm{E}_{\mathrm{a}}$ for the catalysts prepared under different conditions gives a straight line whose slope and intercept are " $\mathrm{h}$ " and "a" respectively. Fig (6) shows the linear plot of $\ln \mathrm{A}$ versus $\Delta \mathrm{E}_{\mathrm{a}}$ for the catalyst prepared under different conditions. The computed values of the constant " $h$ " and "a" are $0.28 \mathrm{~mol} \mathrm{~kJ}^{-1}$ and $4.6 \mathrm{~min}^{-1}$, respectively. The constant " $\mathrm{h} "$ and "a" values indicate that the condition of preparation of the system investigated did not change the dissipation of active sites. i.e. the character of surface heterogeneity. In other words, the conditions of preparation did not change the energetic nature of active site but changed their concentration.

\subsection{Effect of Ageing on Surface Composition, Surface Characteristics and Catalytic Properties of the System Investigated}

The effect of ageing of the mixed solids coprecipitated at a $\mathrm{pH}=7$ and being aged for $1 \mathrm{~h}$ at $70{ }^{\circ} \mathrm{C}$ on their structural, surface and catalytic properties were investigated.

Examination of Table 1 concerning the values of atomic abundance of $\mathrm{Cu}, \mathrm{Zn}, \mathrm{Al}$ and oxygen present in upper most surface layers of samples 3 and 4 shows that: Ageing after precipitation led to increase of copper, Zinc ratio from 1.29 to 1.64 for the solids calcined at $300{ }^{\circ} \mathrm{C}$.

The different surface characteristics of samples 3 and 4 were determined (c.f. Table 3) and the results shows that the ageing after precipitation led to: (i) An increase of the degree of crystallinity of $\mathrm{CuO}$ crystallites. (ii) A decrease in crystallite size of $\mathrm{CuO}$ crystallite from $12.9 \mathrm{~nm}$ to $9.8 \mathrm{~nm}$ for the solids calcined at $300{ }^{\circ} \mathrm{C}$.

It is seen from Table 2 that the ageing process of sample 3 coprecipitated at a $\mathrm{pH}=7$ and $70{ }^{\circ} \mathrm{C}$ for $1 \mathrm{~h}$ led to a measurable increase in its $S_{B E T}$ from 70 to $108 \mathrm{~m}^{2} / \mathrm{g}$ for the sam- 
Table 4. Reaction Rate Constant Per Unit Mass $\left(\mathrm{k} \times 10^{-3} \mathrm{~min}^{-1} \mathrm{~g}^{-1}\right)$ for the Catalytic Oxidation of $\mathrm{CO}$ by $\mathrm{O}_{2} \mathrm{Conducted} \mathrm{at} \mathrm{100-200}$ ${ }^{\circ} \mathrm{C}$ Over $0.5 \mathrm{CuO}-0.5 \mathrm{ZnO}-0.05 \mathrm{Al}_{2} \mathrm{O}_{3}$ System Prepared at Different pH Values at $50{ }^{\circ} \mathrm{C}$ and $70{ }^{\circ} \mathrm{C}$

\begin{tabular}{|c|c|c|c|c|c|}
\hline Solid & Preparation pH & Preparation Temperature & $\mathbf{k}_{\mathbf{1 0 0}}$ & $\mathbf{k}_{\mathbf{1 5 0}}$ & $\mathbf{k}_{\mathbf{2 0 0}}$ \\
\hline \hline Sample 1 & 8.5 & $50^{\circ} \mathrm{C}$ ageing $1 \mathrm{~h}$ at $50^{\circ} \mathrm{C}$ & 96 & 101 & 108 \\
\hline Sample 2 & 9.5 & $50^{\circ} \mathrm{C}$ ageing $1 \mathrm{~h}$ at $50^{\circ} \mathrm{C}$ & 94 & 99 & 108 \\
\hline Sample 3 & 7 & $70^{\circ} \mathrm{C}$ ageing $1 \mathrm{~h}$ at $70^{\circ} \mathrm{C}$ & 54 & 99 & 131 \\
\hline Sample 4 & 7 & $70^{\circ} \mathrm{C}$ without ageing & 92 & 90 & 101 \\
\hline Sample 5 & 9.5 & $70^{\circ} \mathrm{C}$ ageing $1 \mathrm{~h}$ at $70^{\circ} \mathrm{C}$ & 74 & 99 \\
\hline
\end{tabular}

Table 5. Activation Energies $\left(\Delta \mathrm{E}_{\mathrm{a}}\right.$ and $\left.\Delta \mathrm{E}^{*}\right)$ and $\mathrm{In} \mathrm{A}$ for the Catalytic Reaction Carried Out at $100-200{ }^{\circ} \mathrm{C} \mathrm{Over} 0.5 \mathrm{CuO}-0.5 \mathrm{ZnO}$ - $0.05 \mathrm{Al}_{2} \mathrm{O}_{3}$ System Prepared by Coprecipitation and Different $\mathrm{pH}$ Values at $50{ }^{\circ} \mathrm{C}$ and $70{ }^{\circ} \mathrm{C}$ and Being Calcined at $400{ }^{\circ} \mathrm{C}$

\begin{tabular}{|c|c|c|c|c|c|}
\hline Solid & Preparation $\mathbf{p H}$ & Preparation Temperature & $\Delta \mathbf{E}(\mathbf{k J} / \mathbf{m o l})$ & Ln A & \multicolumn{1}{|c|}{$\mathbf{E}^{*}(\mathbf{k J} / \mathbf{m o l})$} \\
\hline \hline Sample 1 & 8.5 & $50{ }^{\circ} \mathrm{C}$ ageing $1 \mathrm{~h}$ at $50{ }^{\circ} \mathrm{C}$ & 1.7 & 5.1 & 2.4 \\
\hline Sample 2 & 9.5 & $50{ }^{\circ} \mathrm{C}$ ageing $1 \mathrm{~h}$ at $50{ }^{\circ} \mathrm{C}$ & 4.6 & 7.0 & 2.2 \\
\hline Sample 3 & 7 & $70{ }^{\circ} \mathrm{C}$ ageing $1 \mathrm{~h}$ at $70^{\circ} \mathrm{C}$ & 10.3 & 6.0 & 2.5 \\
\hline Sample 4 & 7 & $70{ }^{\circ} \mathrm{C}$ without ageing & 5.0 & 5.8 & 2.8 \\
\hline Sample 5 & 9.5 & $70^{\circ} \mathrm{C}$ ageing $1 \mathrm{~h}$ at $70{ }^{\circ} \mathrm{C}$ & 4.6 & & 2.5 \\
\hline
\end{tabular}

ple calcined at $300{ }^{\circ} \mathrm{C}$. However, the ageing process of this particular sample being calcined at $400{ }^{\circ} \mathrm{C}$ exerted an opposite effect, the BET-surface area decreased from 31 to 20 $\mathrm{m}^{2} / \mathrm{g}$. This finding might suggest an effective sintering of the adsorbent subjected to ageing at $70{ }^{\circ} \mathrm{C}$ followed by heating at $400{ }^{\circ} \mathrm{C}$. While the ageing for $1 \mathrm{~h}$ at $70{ }^{\circ} \mathrm{C}$ increased the $\mathrm{S}_{\mathrm{BET}}$ of the adsorbent being calcined at $300{ }^{\circ} \mathrm{C}$ due to an effective departure of most of water of constitution in mixed solids sample being aged at $70{ }^{\circ} \mathrm{C}$ followed by calcination at 300 ${ }^{\circ} \mathrm{C}$. Furthermore, the ageing process brought about a measurable increase in the $\mathrm{Vp}$ value of the adsorbents calcined at 300,350 and $400{ }^{\circ} \mathrm{C}$.

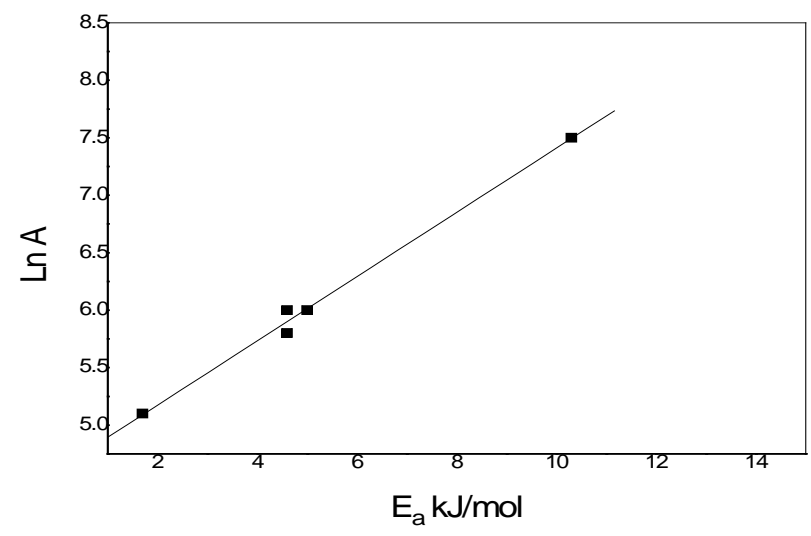

Fig. (6). Relationship between $\mathrm{E}_{\mathrm{a}}$ and $\mathrm{Ln} \mathrm{A}$ for the catalytic oxidation of $\mathrm{CO}$ by $\mathrm{O}_{2}$ carried out at $100{ }^{\circ} \mathrm{C}$ over different samples.

The comparison between the values of the reaction rate constant measured at $100{ }^{\circ} \mathrm{C}$ for catalyst samples 3 and 4 shows that : the ageing process led to a considerable increase in the $\mathrm{k}_{100}$ value from 54 to $92 \mathrm{~min}^{-1} \mathrm{~g}^{-1}$ (an increase of $41 \%$ ). This finding could be attributed to the observed improve- ment in the surface copper zinc ratio and the effective decrease in the crystallite size of $\mathrm{CuO}$ phase. These two parameters dominate the possible negative effect of the decrease in the specific surface area due to the ageing process.

\section{CONCLUSIONS}

The main conclusions derived from the results obtained can be summarized as follows:

1. $\mathrm{CuO} / \mathrm{ZnO}$ having equimolar ratio and treated with $0.05 \mathrm{Al}_{2} \mathrm{O}_{3} / \mathrm{mol}$ catalysts being calcined at $300-400{ }^{\circ} \mathrm{C}$ are composed of nanosized copper and zinc oxides phases.

2. Surface concentration of different atomic species which were strongly dependent on the conditions of preparation and calcination temperatures were bigger than those present in the bulk of different solids.

3. The $\mathrm{S}_{\mathrm{BET}}$ values varied between 21 and $108 \mathrm{~m}^{2} / \mathrm{g}$ depending on the $\mathrm{pH}$ value and calcination temperature. All of the investigated adsorbent consists of mesoporous solids.

4. It seems that not all the surface copper oxide participate directly in chemisorption and catalysis in $\mathrm{CO}$ oxidation reaction as the catalyst having the biggest catalytic activity measured the smallest surface $\mathrm{Cu} / \mathrm{Zn}$ ratio.

5. The computed values of activation energy of $\mathrm{CO}$ oxidation by $\mathrm{O}_{2}(\Delta \mathrm{E})$ over different solids showed small values indicating a big catalytic activity of these solids. The recalculated values of activation energy of the catalyzed reaction $\left(\Delta \mathrm{E}^{*}\right)$ are close to each other within the experimental error $( \pm 0.3 \mathrm{~kJ} / \mathrm{mol})$ showing that the catalytic reaction proceeded via almost the same mechanism over the solids investigated. 
6. The conditions of preparation did not change the energetic nature of active site but change their concentrations.

7. The ageing process of mixed solids coprecipitated at $\mathrm{pH}=7$ and being ageing $1 \mathrm{~h}$ at $70{ }^{\circ} \mathrm{C}$ improved its catalytic performance.

\section{REFERENCES}

[1] Haruta, M.; Yamada, N.; Kobayashi, T.; lijima, S. J. Catal., 1989, 115,301

[2] Moser. W. R. Advanced Catalysts and Nanostructured Materials Academic press, 1996.

[3] Xu, X.; Goodman, D.W. J. Phys. Chem., 1993, 97, 771.

[4] Valden, M.; Lai, X.; Goodman, D.W. Science, 1998, 281, 1647.

[5] McCrea, K.R.; Paker, J.S.; Somorjai, G.A. J. Phys. Chem. B, 2002, 106,10854 .

[6] Scott, R.W.J.; Datye, A.K.; Crooks, R.M. J. Chem. Soc., 2003, 125, 3708 .

[7] Scott, R.W.J.; Wilson, O.M.; Kenik, E.A.; Crooks, R.M. J. Am. Chem. Soc., 2004, 126, 15583.

[8] Scoot, R.W.J.; Sivadinarayana, C.; Wilson, O.M.; Yan, Z.; Goodman, D.W.; Crooks, R.M. J. Am. Chem. Soc., 2005, 127, 1380.

[9] World Health Organization, Carbon monoxide, Environmental Health Criteria 213, World Health Organization, Geneva, 1999.

[10] Gardener, S.D.; Hofiund, G.B.; Upchurch, B.T.; Schryer, D.R.; Kielin, E.J.; Schryer, J. J. Catal.,1991, 129, 114.
[11] Kobayashi, T.; Haruta, M.; Sauno, H.; Nakone, M. Actuators Soc. Auto. Wing., 1988, 3, 339 .

[12] Kobayshi, T.; Haruta, M.; Sauno, H. Chem. Express 1989, 4, 217.

[13] Harrison, P.G.; Willett, M.J. Nature, 1988, 332, 337.

[14] Stark, D.S.; Crocher, A.; Steward, G.J. J. Phys. E: Sci. Instrum., 1983, 16, 126.

[15] Schryer, D.R.; Upchurch, B.I.; Van Norman, J.D.; Brown, K.G.; Schryer, J. J. Catal., 1990, 122, 193.

[16] El-Shobaky, G.A.; Ghozza, A.M. Mater Lett., 2004, 58, 699-705.

[17] El-Shobaky, G.A.; Radwan, N.R.E.; El-Shall, M.S.; Turky, A.M. Hassan M.A. Hassan. Appl. Surf. Sci., 2008, 254(6), 1651.

[18] El-Shobaky, G.A.; Radwan, N.R.E.; El-Shall, M.S.; Turky, A.M.; Hassan M.A. Hassan. Colloids. Surf. A: Physicochem. Eng. Asp., 2007, 311(1-3), 161

[19] Gines, M.J.L.; Amadeo, N.; Laborde, M.; Apesteguia, C.R. Appl. Catal. A, 1995, 131, 283.

[20] Can, Y.; Li, X.; Liu, H. Chin. J. Catal, 2006, 27(3), 210-216.

[21] El-Shobaky, G.A.; Fagal, G.A.; Ghozza, A.M.; Mokhtar, M. Colloids. Surf. A: Physicochem. Eng. Asp., 1998, 142, 17.

[22] Cullity, B.D. Elements of X-ray Diffraction, Addison-wesely Publishing Cos, 2nd ed, Addison-Wesley, Reading, MA, 1978, p. 102.

[23] El-Shobaky, G.A.; El-Khouly, S.M.; Ghozza, A.M.; Mohamed, G.M. Appl. Catal. A., 2006, 302, 296.

[24] Balandin, A.A.; Doki. Akad. Nauk. SSSR 1953, 93, 55

[25] El-Shobaky, G.A.; Fagal, G.A.; Mokhtar, M. Appl. Catal. A, 1997, $155,167$. 